DIGITAL COMMONS
@ UNIVERSITY OF SOUTH FLORIDA

Volume 11

Issue 1 Summer 2021

\section{ABO: Interactive Journal for Women in the Arts, 1640-1830}

\title{
Review of Women, Performance, and the Material of Memory: The Archival Tourist, 1780-1915, by Laura Engel
}

Leslie Ritchie

Queen's University - Kingston, Ontario, ritchiel@queensu.ca

Follow this and additional works at: https://digitalcommons.usf.edu/abo

Part of the Dramatic Literature, Criticism and Theory Commons, Educational Methods Commons, Literature in English, British Isles Commons, and the Women's Studies Commons

\section{Recommended Citation}

Ritchie, Leslie (2021) "Review of Women, Performance, and the Material of Memory: The Archival Tourist, 1780-1915, by Laura Engel," ABO: Interactive Journal for Women in the Arts, 1640-1830: Vol.11: Iss.1, Article 22.

http://doi.org/10.5038/2157-7129.11.1.1248

Available at: https://digitalcommons.usf.edu/abo/vol11/iss1/22

This Reviews is brought to you for free and open access by Digital Commons @ University of South Florida. It has been accepted for inclusion in ABO: Interactive Journal for Women in the Arts, 1640-1830 by an authorized administrator of Digital Commons @ University of South Florida. For more information, please contact digitalcommons@usf.edu. 


\section{Review of Women, Performance, and the Material of Memory: The Archival Tourist, 1780-1915, by Laura Engel}

\section{Keywords}

Sarah Siddons, Fanny Kemble, Amelia M. Watson, photography, portraiture, waxworks, silhouettes, archives, performance

\section{Creative Commons License}

\section{(c) (1) \&}

This work is licensed under a Creative Commons Attribution-Noncommercial 4.0 License 
Laura Engel. Women, Performance, and the Material of Memory: The Archival Tourist, 1780-1915. Palgrave Macmillan, 2019. 169 pp. ISBN 978-1137589316.

Reviewed by Leslie Ritchie

Queen's University

The materials of memory provide this book's original and ambitious structural scaffolding. Engel's book resembles a cabinet of curiosities: each chapter centers on a different physical object, and each object is considered as a repository of memory concerning a professional artist or actress from the eighteenth and nineteenth centuries. The objects are framed in turn by discussions of different visual referential media, ranging from portraiture and silhouettes to waxworks and photography. With her examination of these objects, Engel creates what Allan Sekula has termed a "shadow archive," or an "alternative legacy of actions and performances" (31) that allows for new perspectives on these women's histories. This book's shadow archive traces surprising connections that reach back from Engel herself to photographer-artist Amelia M. Watson; Fanny Kemble, the grand-niece of Sarah Siddons; Siddons's daughters Sally and Maria; and the actress herself.

The book opens by drawing the reader into imagined proximity with the rustling paper dresses created by contemporary artist Isabelle de Borchgrave, who crafts three-dimensional realizations of clothes worn in famous historical portraits of women. The dresses offer viewers a spectacular encounter with storied, embodied objects; they acknowledge viewers' touristic craving for authentic, personal experience, even as their obvious artifice and deceptive performance (imitating sumptuous textiles in paper) subtly mock the pursuit of authenticity. Engel's book, similarly, considers the performance of research as performance, and concerns itself with the ethics of how scholars encounter, evaluate, and represent archival objects. As "critical observers of the past," she contends, scholars "are all archival tourists" (2) when we immerse ourselves in the foreign environment of the archive, performing research that is validated (as is tourism) by the rarity of the experience and of the material and textual objects upon which we train our critical gaze. This book argues that acknowledging that one occupies the position of an archival tourist is a liberating stance that at once admits the scholarly tendency to fetishize archives and shows that approach's gains and limitations. 
Objects resound with recuperative potential in feminist history and historiography, Engel asserts, and the position of the archival tourist offers "a particularly useful strategy for dealing with archival materials by or about eighteenth- and nineteenth-century professional women (actresses, playwrights, and artists), whose unconventional lives and experiences often went unrecorded" or were otherwise distorted by the "accepted narratives of femininity" (3). One fascinating thematic thread that emerges over the course of the book is that such objects can be revelatory of female community among artists-Engel's subjects include affective constellations of mothers and daughters, women who admired or sought to emulate one another, and professional women who worked together.

For instance, the book's second chapter emphasizes the way that Elizabeth Inchbald's pocket diaries (1781-1820) illuminate a collaborative professional relationship between Inchbald and her fellow actress, Mary Wells. Whereas most narratives of their association focus on Wells's madness and the women's subsequent estrangement, the pocket diaries' fragmented entries show the two actresses meeting for meals and excursions and to run lines or work through scripts at Inchbald's home. Inchbald's pocket diary is an "embodied archive ... object and receptacle of information that is literally and figuratively tied to the body" (28) and one that records not only diurnal practicalities but, as Engel observes, the less tangible remains of affect, such as the frustrations and satisfactions that Inchbald experienced as she polished a play. In her later years, Inchbald inscribed her diary with mysterious X's on days when she experienced painful symptoms of an unidentified illness (possibly uterine cancer, 48). Engel inquires whether this shadow archive of recorded pain afforded a possible mode of self-diagnosis (47) for Inchbald as she attempted to alleviate her symptoms with changes to her diet and dress. As Engel thoughtfully expresses it, Inchbald's pocket diary embodies both access and opacity, inviting and resisting the gaze of the archival tourist.

Engel's discussion of the silhouette artists Isabella Beetham and her daughter Jane Read in Chapter 5 curates another shadow archive, this one literally made of shadows; here, she considers the way that silhouettes, "connected to desire, memory, and the politics of exchange," are at once "ghostly and incomplete, while at the same time evoking a material sense of the sitter's presence and embodied reality" (107). Silhouettes' popularity as intimate items of exchange akin to miniature portraits was concurrent with the publication of Lavater's Essays on Physiognomy (translated into English in 1789), which was itself 
illustrated with silhouettes and which promoted the idea that peoples' features might be read to give insight into their characters. Engel reads these artifacts as a "history of forgotten individuals" which, rendered in the elaborate technique of Beetham and Read, falls between "the immediacy of a traditional silhouette and the evocative theatricality of a constructed portrait" $(108,118)$.

In Chapter 6, we marvel at the author's astonishing archival discoveries: first, of an edition of Fanny Kemble's Journal of a Residence on a Georgian Plantation (1864) extra-illustrated with Amelia M. Watson's arresting photographs from her own travels around Kemble's former plantation on St. Simon's Island, Georgia; second, of Watson's notes for an unrealized work that might have included interviews and correspondence from individuals who remembered Kemble and placed those textual remains alongside Watson's photographs. As Engel explains, Watson "set out to translate Fanny Kemble's vexed experiences as the uncomfortable mistress of her husband's plantation in new ways, using new media for new audiences" (134) while simultaneously working through her own position as an artist, often placing portraits of herself in the same landscapes alongside images of her subjects. Engel queries how Watson's photos of African American subjects "highlight the possibilities of new [post-Civil War] identities, freedoms, and subject positions and reinforce traditional images of subservient workers, and anonymous voiceless subjects" (136) and ultimately proposes that these photos may operate as "a type of visual intervention" against an enslaving oppressive gaze (138).

While always attentive to material detail in the objects considered, from brushstrokes in a painting to the possibility of social intervention generated by a photograph's composition, very occasionally the narrative absents or footnotes the body of the scholarly observer, with a corresponding diminution of immediacy. In Chapter 4, which concerns an auction of the Countess of Blessington's goods, the reader misses the staging of the scholarly archival encounter, as the position of tourist is occupied by those attending the auction's display and aiding in the chaotic dispersal of the Countess's material archive. By contrast, the moment of the book most attendant to tourists' bodies experiencing simulacra and archive occurs in the epilogue's lively description of a waxwork and multi-sensory-media exhibition centred on the Empress Elizabeth of Austria entitled "The Sisi Experience" (Vienna, 2017). The multiple mirrors that confront the tourist moving through this exhibition aptly symbolize the archival tourist's performative complicity in interacting with the display to create meaning. 
As is appropriate to a volume focussing on material objects, there are abundant, well-chosen illustrations. Indeed, both the research from the book and its methodology might be said to open out into the material: the discussion of shimmering white dresses featured in the third chapter is realized in many images featured in the exhibition "Artful Nature: Fashion and Theatricality, 1770-1830," at the Lewis Walpole Library in Farmington, Connecticut (6 February-22 May 2020), curated by the author, Laura Engel, and Amelia Rause, and now archived online.

How best to translate bodily presence across time and space through considerations of specific objects (159) remains an open question, but this book models some valuable approaches. To be an archival tourist is to be open to the affect generated by the tactile and sensory dimensions of archival objects, to welcome a sense of play and indeterminacy as we situate these objects within a range of possible interpretations, and to foreground our own practices of surveillance and projection as we perform interpretive acts. Engel's sense of wonder at the materials of memory is everywhere apparent, and her eloquent appreciation of their research potential is one of the abiding joys of this book. 